\title{
Distinct roles for the kidney and systemic tissues in blood pressure regulation by the renin-angiotensin system
}

\author{
Steven D. Crowley, ${ }^{1}$ Susan B. Gurley, ${ }^{1}$ Michael I. Oliverio, ${ }^{1}$ A. Kathy Pazmino, ${ }^{1}$ Robert Griffiths, ${ }^{1}$
} Patrick J. Flannery, ${ }^{1}$ Robert F. Spurney, ${ }^{1}$ Hyung-Suk Kim, ${ }^{2}$ Oliver Smithies, ${ }^{2}$ Thu H. Le, ${ }^{1}$ and Thomas M. Coffman'

1Division of Nephrology, Department of Medicine, Duke University and Durham VA Medical Centers, Durham, North Carolina, USA. 2Department of Pathology, University of North Carolina, Chapel Hill, North Carolina, USA.

\begin{abstract}
Angiotensin II, acting through type 1 angiotensin $\left(\mathrm{AT}_{1}\right)$ receptors, has potent effects that alter renal excretory mechanisms. Control of sodium excretion by the kidney has been suggested to be the critical mechanism for blood pressure regulation by the renin-angiotensin system (RAS). However, since $\mathbf{A T}_{1}$ receptors are ubiquitously expressed, precisely dissecting their physiological actions in individual tissue compartments including the kidney with conventional pharmacological or gene targeting experiments has been difficult. Here, we used a cross-transplantation strategy and $\mathrm{AT}_{1 \mathrm{~A}}$ receptor-deficient mice to demonstrate distinct and virtually equivalent contributions of $\mathrm{AT}_{1}$ receptor actions in the kidney and in extrarenal tissues to determining the level of blood pressure. We demonstrate that regulation of blood pressure by extrarenal $\mathrm{AT}_{1 \mathrm{~A}}$ receptors cannot be explained by altered aldosterone generation, which suggests that $\mathrm{AT}_{1}$ receptor actions in systemic tissues such as the vascular and/or the central nervous systems make nonredundant contributions to blood pressure regulation. We also show that interruption of the $\mathrm{AT}_{1}$ receptor-mediated short-loop feedback in the kidney is not sufficient to explain the marked stimulation of renin production induced by global $\mathrm{AT}_{1}$ receptor deficiency or by receptor blockade. Instead, the renin response seems to be primarily determined by renal baroreceptor mechanisms triggered by reduced blood pressure. Thus, the regulation of blood pressure by the RAS is mediated by $\mathrm{AT}_{1}$ receptors both within and outside the kidney.
\end{abstract}

\section{Introduction}

The renin-angiotensin system (RAS), acting through type 1 angiotensin $\left(\mathrm{AT}_{1}\right)$ receptors, is a master regulator of fluid homeostasis (1). The critical role of this pathway in regulation of blood pressure is highlighted by the impressive efficacy of angiotensinconverting enzyme (ACE) inhibitors and angiotensin receptor blockers (ARBs) in patients with hypertension and in mice lacking the $\mathrm{AT}_{1 \mathrm{~A}}$ receptor, the major murine $\mathrm{AT}_{1}$ receptor isoform. These animals have very low blood pressure and profound salt sensitivity $(2,3)$. Control of sodium excretion by the kidney has been suggested to be the critical mechanism for blood pressure regulation by the RAS (4). However, as $\mathrm{AT}_{1}$ receptors are ubiquitously expressed, precisely dissecting and quantifying their physiological actions in individual tissue compartments including the kidney has been difficult. Accordingly, there is no direct proof of the primacy of the kidney in regulation of blood pressure by the RAS.

At the cellular level, responsiveness to angiotensin II is conferred by expression of angiotensin receptors. Angiotensin receptors can be divided into 2 pharmacological classes, type $1\left(\mathrm{AT}_{1}\right)$ and type 2 $\left(\mathrm{AT}_{2}\right)$, based on their differential affinities for various nonpeptide antagonists (5). Studies using these antagonists suggested that most of the classically recognized functions of the RAS are medi-

Nonstandard abbreviations used: ACE, angiotensin-converting enzyme; ARB, angiotensin receptor blocker; $\mathrm{AT}_{1}$, type 1 angiotensin; JGA, juxtaglomerular apparatus; RAS, renin-angiotensin system.

Conflict of interest: The authors have declared that no conflict of interest exists.

Citation for this article: J. Clin. Invest. 115:1092-1099 (2005).

doi:10.1172/JCI200523378. ated by $\mathrm{AT}_{1}$ receptors (6). Gene targeting studies confirmed these conclusions (7). $\mathrm{AT}_{1}$ receptors from a number of species have been cloned $(8,9)$, and 2 subtypes, designated $\mathrm{AT}_{1 \mathrm{~A}}$ and $\mathrm{AT}_{1 \mathrm{~B}}$, have been identified in rat and mouse (10). The murine $\mathrm{AT}_{1}$ receptors are products of separate genes and share substantial sequence homology (10). $\mathrm{AT}_{1 \mathrm{~A}}$ receptors predominate in most organs, except the adrenal gland and regions of the $\mathrm{CNS}$, where $\mathrm{AT}_{1 \mathrm{~B}}$ expression may be more prominent (10). A single report has suggested that $\mathrm{AT}_{1 \mathrm{~B}}$ receptors might also exist in humans (11), but this has not been confirmed in the unpublished work of several independent groups, and the consensus view is that there is no human counterpart to the murine $\mathrm{AT}_{1 \mathrm{~B}}$ receptor. Thus, the $\mathrm{AT}_{1 \mathrm{~A}}$ receptor is considered the closest murine homolog to the single human $\mathrm{AT}_{1}$ receptor.

$\mathrm{AT}_{1}$ receptors can be found in organ systems that play key roles in blood pressure homeostasis, including the heart, kidney, blood vessels, adrenal glands, and cardiovascular control centers in the brain (5). In the vascular system, stimulation of $\mathrm{AT}_{1}$ receptors causes potent vasoconstriction (2). In the adrenal cortex, their activation stimulates the release of aldosterone (12), thereby promoting sodium reabsorption in the mineralocorticoid-responsive segments of the distal nephron (13). In the brain, intraventricular injection of angiotensin II causes a dramatic pressor response mediated by $\mathrm{AT}_{1}$ receptors (14). In the kidney, activation of $\mathrm{AT}_{1}$ receptors is associated with renal vasoconstriction and antinatriuresis $(15,16)$. Furthermore, it has been suggested that activation of $\mathrm{AT}_{1}$ receptors at the juxtaglomerular apparatus suppresses renin release through the so-called short-loop feedback mechanism (17, 18). While $\mathrm{AT}_{1}$ receptors have actions in myriad tissues that could potentially influence blood pressure, a prevailing view is that the 

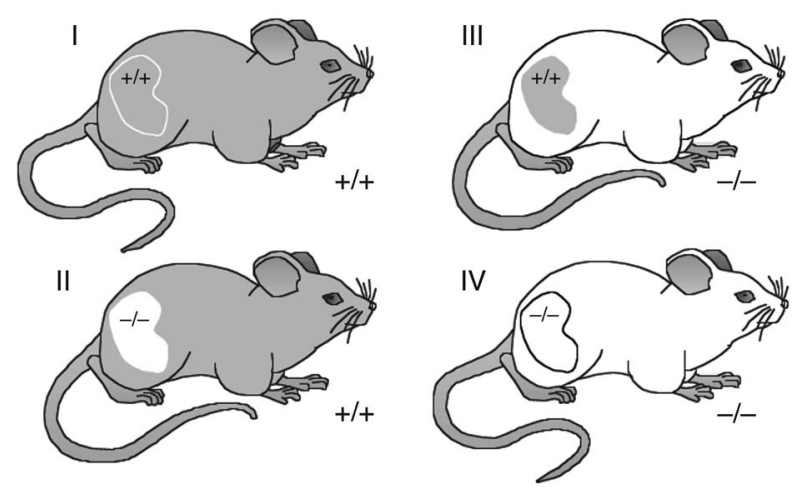

Figure 1

Kidney cross-transplantation groups. Wild-type $(+/+)$ or $\mathrm{AT}_{1 \mathrm{~A}}$ receptordeficient $(-/-)$ mice were transplanted with a wild-type or $\mathrm{AT}_{1 \mathrm{~A}}$ receptor-deficient kidney. Nephrectomies were performed as described in Methods. Group I animals $\left(D^{+} R^{+}\right)$had a full complement of $A T_{1 A}$ receptors. Group II animals $\left(D^{-} R^{+}\right)$expressed $A T_{1 A}$ receptors only outside the kidney. Group III animals $\left(D^{+} R^{-}\right)$expressed $A T_{1 A}$ receptors only within the kidney. Group IV animals $\left(D^{-} R^{-}\right)$completely lacked $A T_{1 A}$ receptors. Recipients retained their own adrenal glands. $n \geq 6$ per group.

actions of the RAS to influence kidney function are dominant in chronic control of blood pressure $(4,19)$. Identifying the tissues and cell lineages responsible for blood pressure regulation by the RAS will provide novel insights into the integrated control of blood pressure and will more precisely define the mechanisms of the antihypertensive actions of ACE inhibitors and ARBs. Here, we used a cross-transplantation strategy and $\mathrm{AT}_{1 \mathrm{~A}}$ receptor-deficient mice to demonstrate distinct and virtually equivalent contributions of $\mathrm{AT}_{1}$ receptor actions in the kidney and in extrarenal tissues to determining the level of blood pressure.

\section{Results}

Cross-transplantation strategy. In order to define the relative importance of renal versus nonrenal $\mathrm{AT}_{1}$ receptor pools in blood pressure regulation by the RAS, we carried out cross-transplantation experiments, performing fully vascularized kidney transplants between genetically matched $\mathrm{F}_{1}(\mathrm{C} 57 \mathrm{BL} / 6 \times 129)$ wild-type mice and mice homozygous for a targeted disruption of the Agtrla gene locus encoding the $\mathrm{AT}_{1 \mathrm{~A}}$ receptor. In the resulting recipient animals, both adrenal glands were retained. As shown in Figure 1, by varying the genotype of the transplant donors and recipients, we generated 4 groups of animals in which renal function was provided entirely by the single transplanted kidney. Group I animals were Agtr1a/++ recipients $\left(\mathrm{R}^{+}\right)$that were transplanted with kidneys from Agtr $1 a^{+/+}$donors $\left(\mathrm{D}^{+}\right)$and thus had normal expression of $\mathrm{AT}_{1 \mathrm{~A}}$ receptors in the donor renal and recipient nonrenal tissues $\left(D^{+} R^{+}\right)$. We will refer to group I as the $D^{+} R^{+}$group, since $A T_{1 \mathrm{~A}}$ receptors were present in both kidney and somatic tissues. Group II animals lacked expression of $\mathrm{AT}_{1 \mathrm{~A}}$ receptors

\section{Figure 2}

Radiotelemetry blood pressure in untransplanted wild-type and $\mathrm{AT}_{1 \mathrm{~A}}$ receptor-deficient $\left(\right.$ Agtr1a $\left.^{-/-}\right)$mice. (A) Blood pressure is reduced in $\mathrm{Agtr1a}^{-/-}$mice (black bar) vs. wild-type controls (white bar); ${ }^{*} P=0.03 ; n \geq 4$ per group. (B) Preservation of diurnal blood pressure variation in Agtr1 $^{-1-}$ mice. MAP, mean arterial pressure. 3P, 3 pm; 12A, 12 am. in the kidney, but had normal expression of receptors in systemic tissues $\left(\mathrm{D}^{-} \mathrm{R}^{+}\right)$. In group III, $\mathrm{AT}_{1 \mathrm{~A}}$ receptors were present in the kidney but absent from all nonrenal tissues $\left(D^{+} R^{-}\right)$. Finally, group IV mice were completely deficient in $\mathrm{AT}_{1 \mathrm{~A}}$ receptors $\left(\mathrm{D}^{-} \mathrm{R}^{-}\right)$.

Blood pressure measurements in Agtr1 $a^{+/+}$and Agtr1 $a^{-/-}$mice. In order to accurately measure blood pressures in conscious, unrestrained animals, we implanted radiotelemetry transmitters. Using this approach, we first measured blood pressures in otherwise unma-

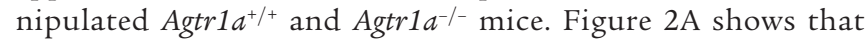
blood pressures were significantly reduced in $\mathrm{F}_{1}(\mathrm{C} 57 \mathrm{BL} / 6 \times 129)$ Agtr1 $\mathrm{a}^{-/-}$mice $(89 \pm 8 \mathrm{mmHg})$ compared with wild-type controls $(112 \pm 3 \mathrm{mmHg} ; P=0.03)$. The magnitude of the blood pressure reduction in Agtr1a-/- animals was very similar to that observed in our previous experiments using tail cuff manometry (2). We also analyzed a series of 24-hour blood pressure recordings and found that the general nature of blood pressure fluctuations was similar in Agtr $1 a^{+/+}$and Agtr1 $a^{-/-}$mice (Figure 2B), which indicated that the absence of $\mathrm{AT}_{1 \mathrm{~A}}$ receptors does not affect qualitative patterns of diurnal variation in blood pressure.

Distinct contributions of renal and systemic $A T_{1}$ receptors to blood pressure homeostasis. Among the transplanted animals, blood pressures in group $\mathrm{I}\left(\mathrm{D}^{+} \mathrm{R}^{+}\right)$were very similar to those of nontransplanted, Agtr $1 a^{+/+}$control mice (118 \pm 5 vs. $112 \pm 3 \mathrm{mmHg} ; P=0.44$ ), which indicated that the transplant procedure does not significantly alter blood pressure. Figure 3 shows that the absence of $A_{1 \mathrm{~A}}$ receptors in the kidney alone in group II $\left(\mathrm{D}^{-} \mathrm{R}^{+}\right)$animals was associated with a significant reduction in blood pressure compared with the $\mathrm{D}^{+} \mathrm{R}^{+}$ group ( $99 \pm 4$ vs. $118 \pm 5 \mathrm{mmHg} ; P=0.006$ vs. $\left.\mathrm{D}^{+} \mathrm{R}^{+}\right)$. This finding is consistent with the prevailing view that regulation of sodium handling by the kidney is a major determinant of the chronic level of blood pressure and indicates that the absence of $\mathrm{AT}_{1 \mathrm{~A}}$ receptor pathways in the kidney alone is sufficient to lower blood pressure. However, blood pressures were similarly reduced in group III $\left(D^{+} R^{-}\right)$mice, which lack $\mathrm{AT}_{1 \mathrm{~A}}$ receptors in systemic tissues but have normal renal expression of $\mathrm{AT}_{1 \mathrm{~A}}$ receptors $(99 \pm 2 \mathrm{vs.} 118 \pm 5$ $\mathrm{mmHg} ; P=0.006)$. Thus, $\mathrm{AT}_{1 \mathrm{~A}}$ receptors in nonrenal tissues also make a nonredundant contribution to the determination of the blood pressure level. Moreover, the presence of intact $\mathrm{AT}_{1 \mathrm{~A}}$ receptor pathways in the kidneys of these animals does not compensate for the absence of receptors outside of the kidney. With respect to blood pressure homeostasis, the finding that blood pressures were virtually identical in the $\mathrm{D}^{-} \mathrm{R}^{+}$and $\mathrm{D}^{+} \mathrm{R}^{-}$groups indicates that the contributions of $\mathrm{AT}_{1 \mathrm{~A}}$ receptors in the kidney and systemic tissues are very similar in magnitude.

Blood pressures were further reduced in group IV ( $\left.\mathrm{D}^{-} \mathrm{R}^{-}\right)$animals, which completely lack $\mathrm{AT}_{1 \mathrm{~A}}$ receptors $(86 \pm 3 \mathrm{mmHg} ; P=0.02$
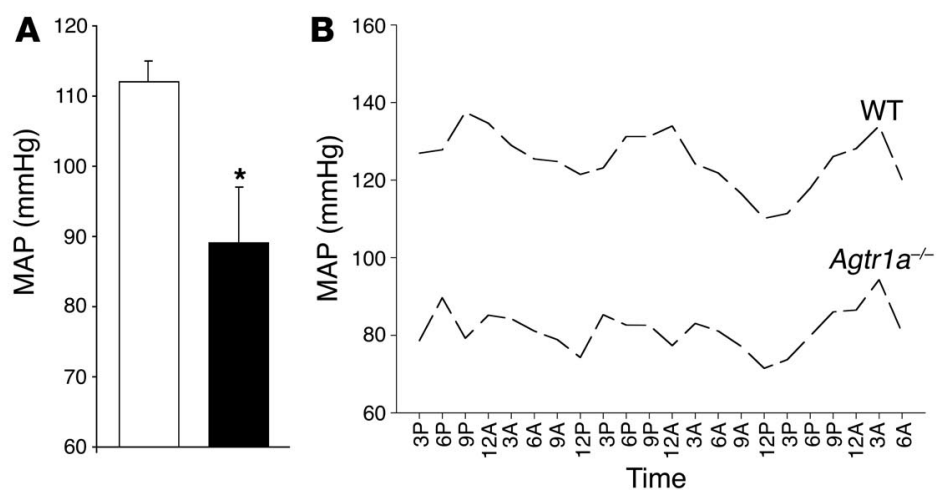


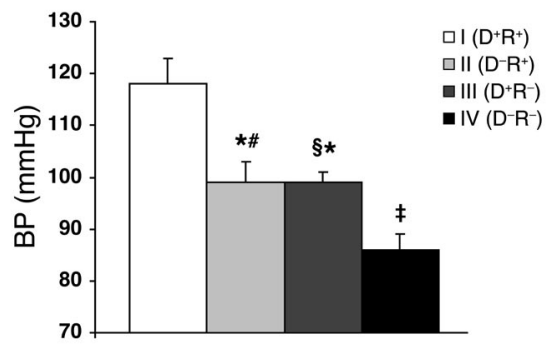

Figure 3

Blood pressures in the cross-transplantation groups measured by radiotelemetry. ${ }^{\star} P=0.006$ vs. group I; $\# P=0.02$ vs. group IV; $\$ P=0.002$ vs. group IV; $¥ P=0.00007$ vs. group I ( $n \geq 6$ per group).

vs. $\mathrm{D}^{-} \mathrm{R}^{+} ; P=0.002$ vs. $\left.\mathrm{D}^{+} \mathrm{R}^{-}\right)$. This suggests that the mechanisms for control of blood pressure by systemic and renal $\mathrm{AT}_{1 \mathrm{~A}}$ receptors are nonoverlapping. Finally, blood pressures in $\mathrm{D}^{-} \mathrm{R}^{-}$animals were very similar to those measured in intact, nontransplanted Agtr1 $\mathrm{a}^{-/-}$ mice $(89 \pm 8 \mathrm{mmHg})$, which further illustrates the lack of any significant impact of the transplant procedure on blood pressure.

Effects of oral sodium loading on blood pressures. To assess the impact of altered sodium homeostasis on blood pressure regulation in the experimental groups, we examined the effects of high-salt feeding. After baseline blood pressures of mice on the normal $(0.4 \% \mathrm{NaCl})$ diet were established, mice in each experimental group were fed a high-salt $(6 \% \mathrm{NaCl})$ diet, and blood pressures were simultaneously monitored. As shown in Figure 4, the high-salt diet caused significant increases in blood pressures only in the $\mathrm{D}^{-} \mathrm{R}^{+}(14.2 \% \pm 5 \%$ [from $99 \pm 4$ to $114 \pm 9 \mathrm{mmHg}$ ]; $P=0.03$ vs. normal salt) and the $\mathrm{D}^{-} \mathrm{R}^{-}(20.1 \% \pm 4.9 \%$ [from $85 \pm 3$ to $102 \pm 5 \mathrm{mmHg}$ ]; $P=0.01$ vs. normal salt) groups, lacking $\mathrm{AT}_{1 \mathrm{~A}}$ receptors in the kidney. By contrast, in the $\mathrm{D}^{+} \mathrm{R}^{+}$or $\mathrm{D}^{+} \mathrm{R}^{-}$groups with a normal complement of renal $\mathrm{AT}_{1 \mathrm{~A}}$ receptors, high-salt feeding did not significantly affect blood pressures $\left(118 \pm 5\right.$ to $122 \pm 7 \mathrm{mmHg}$ for $\mathrm{D}^{+} \mathrm{R}^{+}, 99 \pm 2$ to $105 \pm 3 \mathrm{mmHg}$ for $\mathrm{D}^{+} \mathrm{R}^{-} ; P=$ not significant vs. normal salt in both groups). Thus, the absence of $\mathrm{AT}_{1 \mathrm{~A}}$ receptors in the kidney was associated with sodium sensitivity, whereas groups with normal renal $\mathrm{AT}_{1 \mathrm{~A}}$ receptor expression were sodium resistant.

Extrarenal $A T_{1 A}$ receptors, aldosterone, and blood pressure. As discussed above, there are a number of direct actions of $A_{1}$ receptors that impact on blood pressure (19). In addition, $\mathrm{AT}_{1}$ receptors in the zona glomerulosa of the adrenal gland indirectly affect blood pressure by stimulating aldosterone release and, in turn, promoting sodium reabsorption by the distal nephron $(12,13)$. We therefore considered the possibility that impaired aldosterone release might explain the blood pressure reduction that we observed in $\mathrm{D}^{+} \mathrm{R}^{-}$mice, which lack $\mathrm{AT}_{1 \mathrm{~A}}$ receptors in systemic tissues. To test this, we collected urine from animals in each of the experimental groups and measured urinary aldosterone levels by ELISA.

As shown in Figure 5, aldosterone excretion was equivalent in the $\mathrm{D}^{+} \mathrm{R}^{+}$and $\mathrm{D}^{-} \mathrm{R}^{+}$groups $(2,395 \pm 260$ vs. $3,177 \pm 649 \mathrm{pg} / 24 \mathrm{~h})$, which is consistent with the fact that they have normal complements of adrenal $\mathrm{AT}_{1 \mathrm{~A}}$ receptors. In contrast, aldosterone excretion was reduced by approximately $50 \%$ in $\mathrm{D}^{+} \mathrm{R}^{-}$animals, lacking $\mathrm{AT}_{1 \mathrm{~A}}$ receptors in nonrenal tissues including the adrenal glands $\left(1,158 \pm 207 \mathrm{pg} / 24 \mathrm{~h} ; P=0.005\right.$ vs. $\mathrm{D}^{+} \mathrm{R}^{+} ; P=0.01$ vs. $\left.\mathrm{D}^{-} \mathrm{R}^{+}\right)$, which suggests that the impaired aldosterone response in these animals is the cause of their reduced blood pressure. The aldosterone excretion in the $\mathrm{D}^{-} \mathrm{R}^{-}$mice, which completely lack $\mathrm{AT}_{1 \mathrm{~A}}$ receptors, was significantly higher than that in the $\mathrm{D}^{+} \mathrm{R}^{-}$group $(2,643 \pm 441$ $\mathrm{pg} / 24 \mathrm{~h} ; P<0.05)$. Since the adrenal glands in $\mathrm{D}^{-} \mathrm{R}^{-}$mice also lack $\mathrm{AT}_{1 \mathrm{~A}}$ receptors, this augmented aldosterone excretion is likely due to marked renin stimulation (see below) generating a high level of angiotensin II that stimulates the $\mathrm{AT}_{1 \mathrm{~B}}$ receptors in the adrenal cortex. Other pathways for aldosterone stimulation may also play a role (20). Yet blood pressures are significantly lower in $\mathrm{D}^{-} \mathrm{R}^{-}$mice completely lacking $\mathrm{AT}_{1 \mathrm{~A}}$ receptors compared with those in the $\mathrm{D}^{+} \mathrm{R}^{-}$group, despite their higher aldosterone levels.

To determine whether lower aldosterone production in the $\mathrm{D}^{+} \mathrm{R}^{-}$ animals accounts for their lower blood pressures versus the $\mathrm{D}^{+} \mathrm{R}^{+}$ group, we performed an additional experiment using adrenalectomized $\mathrm{D}^{+} \mathrm{R}^{+}$and $\mathrm{D}^{+} \mathrm{R}^{-}$animals in which aldosterone levels were clamped by the infusion of equivalent amounts of aldosterone via an osmotic minipump. As shown in Figure 6A, infusing aldosterone at $1 \mu \mathrm{g} /$ day provided supraphysiological aldosterone replacement, since urinary aldosterone excretion was increased almost 4-fold in the infused mice compared with mice with intact adrenal glands $(P=0.005)$. Nevertheless, this enhanced level of aldosterone had no effect on blood pressure in the $\mathrm{D}^{+} \mathrm{R}^{+}$groups $(118 \pm 1$ vs. $118 \pm 5$ $\mathrm{mmHg} ; \mathrm{P}=$ not significant). Moreover, urinary aldosterone excretion was not significantly different between the adrenalectomized $\mathrm{D}^{+} \mathrm{R}^{+}$and adrenalectomized $\mathrm{D}^{+} \mathrm{R}^{-}$groups that received aldosterone infusions $(8,020 \pm 2,627$ vs. $8,828 \pm 1,364 \mathrm{pg} / 24 \mathrm{~h}$, respectively; $P=$ not significant). However, despite supraphysiological and equivalent aldosterone levels, blood pressures were significantly reduced in the aldosterone-infused $\mathrm{D}^{+} \mathrm{R}^{-}$group compared with the $\mathrm{D}^{+} \mathrm{R}^{+}$group $(106 \pm 1$ vs. $118 \pm 1 \mathrm{mmHg} ; P<0.0001)$ as shown in Figure $6 \mathrm{~B}$. These data demonstrate that regulation of blood pressure by extrarenal $\mathrm{AT}_{1 \mathrm{~A}}$ receptors cannot be explained by changes in aldosterone generation, which indicates that $\mathrm{AT}_{1}$ receptor actions in other systemic tissues make nonredundant contributions to blood pressure regulation.

Extrarenal $A T_{1 A}$ receptors and renal sympathetic innervation. The sympathetic nervous system, acting through renal nerves can modulate sodium handling by the kidney (21). As $\mathrm{AT}_{1}$ receptors in the CNS can stimulate sympathetic tone $(22,23)$, we considered the possibility that altered neural input to the kidney might represent a mechanism for the altered blood pressures in the $\mathrm{D}^{+} \mathrm{R}^{-}$group. Furthermore, since the renal pedicle is transected in the course of harvesting the donor kidney, renal innervation may be impaired in this model. To examine these possibilities, we compared renal norepinephrine content in the $\mathrm{D}^{+} \mathrm{R}^{+}$and $\mathrm{D}^{+} \mathrm{R}^{-}$groups with that of kidneys from Agtr1 $a^{+/+}$and Agtr1a-/- mice. Norepinephrine content

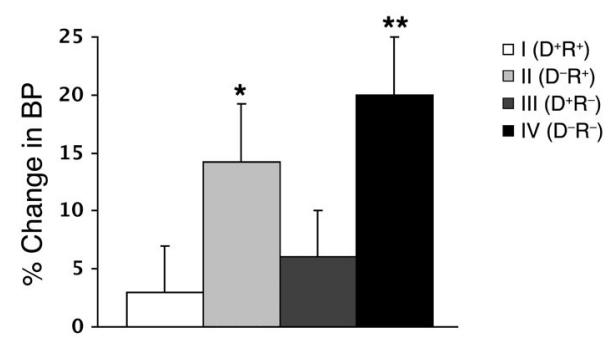

\section{Figure 4}

Effects of oral salt loading on blood pressure. Mice were fed a diet with high $(6 \% \mathrm{NaCl})$ salt content. The percent change in blood pressure relative to the baseline blood pressure on a normal $(0.4 \% \mathrm{NaCl})$ salt diet is shown. ${ }^{\star} P=0.03$ vs. normal salt; ${ }^{*} P=0.01$ vs. normal salt ( $n \geq 5$ per group). 


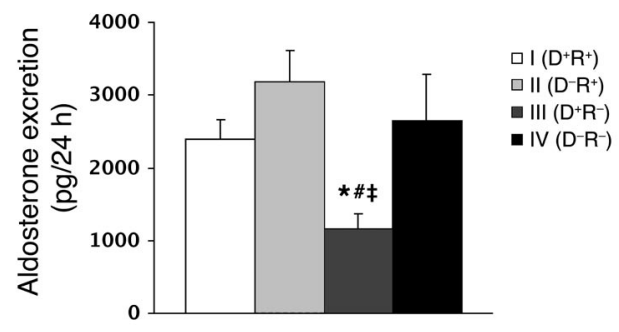

Figure 5

Urinary aldosterone excretion in the cross-transplantation groups. Urine samples were collected over 24 hours from mice in metabolic cages. Aldosterone was quantitated by ELISA (pg/24 h). ${ }^{*} P=0.005$ vs. group l; $\# P=0.01$ vs. group II; $¥ P<0.05$ vs. group IV ( $n \geq 6$ per group).

is an accepted measure of renal sympathetic nerve activity (24). As shown in Figure 7, renal norepinephrine content was reduced significantly in both groups of transplanted kidneys compared with those in $A g t r 1 a^{+/+}$controls $(P<0.001)$, which suggested that significant re-innervation of the transplanted kidneys had not occurred during the period of study. As there was no difference in norepinephrine levels between kidneys from the Agtr $1 a^{+/+}$and Agtr1 $1 \mathrm{a}^{-/-}$mice $(1,094 \pm 132$ vs. $1,286 \pm 79 \mathrm{ng} / \mathrm{g})$, the absence of $\mathrm{AT}_{1 \mathrm{~A}}$ receptors does not substantially affect renal norepinephrine content in the presence of intact renal nerves. Furthermore, norepinephrine levels were virtually identical in kidneys of the $\mathrm{D}^{+} \mathrm{R}^{+}$and $\mathrm{D}^{+} \mathrm{R}^{-}$mice $(173 \pm 53 \mathrm{vs} .163 \pm 75 \mathrm{ng} / \mathrm{g})$, which indicates that altered sympathetic nerve input in the kidney cannot explain the reduced blood pressures in the $\mathrm{D}^{+} \mathrm{R}^{-}$animals.

Renal $A T_{1 A}$ receptors and regulation of renin. Angiotensin II may regulate its own synthesis by activation of $\mathrm{AT}_{1}$ receptors at the juxtaglomerular apparatus (JGA), suppressing renin release (18). As this is one of several intrarenal actions of $\mathrm{AT}_{1 \mathrm{~A}}$ receptors that could affect blood pressure, we examined the impact of renal and systemic $\mathrm{AT}_{1 \mathrm{~A}}$ receptors on renin $\mathrm{mRNA}$ expression in the kidney.

We found that renin mRNA levels in transplanted kidneys of $\mathrm{D}^{+} \mathrm{R}^{+}$animals $(29 \pm 8 \mathrm{pg}$ of renin mRNA/ $\mu$ g total mRNA) were nearly identical to those of unmanipulated kidneys from wild-type mice ( $25 \pm 4 \mathrm{pg}$ of renin $\mathrm{mRNA} / \mu \mathrm{g}$ total $\mathrm{mRNA}$ ). In previous studies, we and others have described markedly enhanced renin expression and JGA hypertrophy in Agtr1 $1 a^{-/-}$mice with generalized deficiency of $\mathrm{AT}_{1 \mathrm{~A}}$ receptors $(25,26)$. However, as shown in Figure 8, this phenotype was not recapitulated in $\mathrm{D}^{-} \mathrm{R}^{+}$animals, which lack $\mathrm{AT}_{1 \mathrm{~A}}$ receptors only in the kidney. While kidney renin mRNA levels tended to be higher in $\mathrm{D}^{-} \mathrm{R}^{+}$mice $(59 \pm 19 \mathrm{pg}$ of renin mRNA/ $\mu \mathrm{g}$ total mRNA) than in the $\mathrm{D}^{+} \mathrm{R}^{+}$group, this difference was not statistically significant $(P=0.18)$. Thus, the absence of $\mathrm{AT}_{1 \mathrm{~A}}$ receptors only in the kidney and the consequent lack of short-loop feedback did not markedly alter renin mRNA levels. Similarly, the absence of $\mathrm{AT}_{1 \mathrm{~A}}$ receptors only in nonrenal tissues of $\mathrm{D}^{+} \mathrm{R}^{-}$animals had no effect on renin expression ( $22 \pm 14 \mathrm{pg}$ of renin mRNA/ $\mu \mathrm{g}$ total mRNA) compared with the $\mathrm{D}^{+} \mathrm{R}^{+}$group (Figure 8 ). By contrast, the simultaneous absence of $\mathrm{AT}_{1 \mathrm{~A}}$ receptors in both renal and nonrenal tissues of $\mathrm{D}^{-} \mathrm{R}^{-}$animals was associated with a marked upregulation of renin expression to $708 \pm 161 \mathrm{pg}$ of renin $\mathrm{mRNA} / \mu \mathrm{g}$ total mRNA ( $P<0.003$ vs. all other groups). Based on the findings from the $\mathrm{D}^{-} \mathrm{R}^{+}$ group, interruption of short-loop feedback in the kidney cannot explain the more than 10-fold increase in renin mRNA levels in the $\mathrm{D}^{-} \mathrm{R}^{-}$group. Accordingly, we postulate that this marked augmentation in renin expression is due to the lower blood pressures in this group. Moreover, since blood pressure reductions of almost 20 $\mathrm{mmHg}$ in the $\mathrm{D}^{-} \mathrm{R}^{+}$and $\mathrm{D}^{+} \mathrm{R}^{-}$groups were not sufficient to trigger this response, our data suggest that a threshold of blood pressure lowering must be achieved for activation of baroreceptor mechanisms that stimulate renin $(27,28)$.

We performed additional experiments to examine the contribution of blood pressure to the stimulation of renin seen in the complete absence of $\mathrm{AT}_{1 \mathrm{~A}}$ receptors. To this end, we measured blood pressure and renin mRNA expression in $\mathrm{D}^{-} \mathrm{R}^{-}$mice fed a high-salt $(6 \% \mathrm{NaCl})$ diet. As in our previous experiments on unmanipulated Agtr1 $a^{-/-}$mice (3), high-salt feeding caused a significant increase in blood pressure in the $\mathrm{D}^{-} \mathrm{R}^{-}$mice $(102 \pm 5 \mathrm{mmHg})$ compared with $\mathrm{D}^{-} \mathrm{R}^{-}$mice fed a normal $(0.4 \% \mathrm{NaCl})$ diet $(86 \pm 3 \mathrm{mmHg} ; P=0.01)$. The blood pressures in the $\mathrm{D}^{-} \mathrm{R}^{-}$animals fed a high-salt diet increased sufficiently, becoming not significantly different from those of the $\mathrm{D}^{-} \mathrm{R}^{+}$and $\mathrm{D}^{+} \mathrm{R}^{-}$groups on a normal diet $(99 \pm 4$ and $99 \pm 2 \mathrm{mmHg}$ in $\mathrm{D}^{-} \mathrm{R}^{+}$and $\mathrm{D}^{+} \mathrm{R}^{-}$groups, respectively). This normalized blood pressure in the high-salt $\mathrm{D}^{-} \mathrm{R}^{-}$group was associated with a dramatic suppression of renin mRNA levels $(130 \pm 58 \mathrm{pg}$ of renin mRNA/ $\mathrm{Mg}$ total mRNA) compared with the $\mathrm{D}^{-} \mathrm{R}^{-}$animals on the normal diet $(708 \pm 161 \mathrm{pg}$ of renin $\mathrm{mRNA} / \mu \mathrm{g}$ total $\mathrm{mRNA} ; P=0.003)$.

\section{Discussion}

The important role of the kidney in regulation of blood pressure has been long recognized (29), and the relationship between alterations in systemic blood pressure and changes in renal sodium excretion is well documented (30). For example, an elevation in perfusion pressure in the renal artery results in a rapid increase in sodium and water excretion by the kidney, so-called pressure natriuresis (30). Based on such observations, Guyton and coworkers suggested that whenever arterial pressure is elevated, activation of this pressurenatriuresis mechanism will cause sufficient excretion of sodium and water to return systemic pressures to normal (31). Because of its potent actions to modulate renal sodium excretion, angiotensin II has been implicated as a major determinant of these pressurenatriuresis relationships $(19,32)$. These actions may be mediated by direct effects of $\mathrm{AT}_{1}$ receptors on renal resistance vessels and epithelial cells or indirectly through stimulation of aldosterone production via $\mathrm{AT}_{1}$ receptors in the adrenal gland (32).

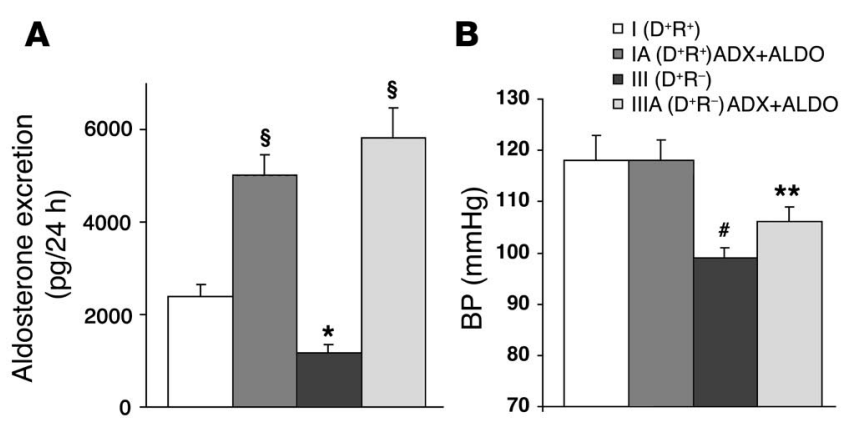

Figure 6

Aldosterone clamp experiment. Adrenalectomies (ADX) were performed at the time of native nephrectomies. Osmotic minipumps containing aldosterone (ALDO) were implanted at the time of second nephrectomy/adrenalectomy. (A) Urine samples were collected over 24 hours for aldosterone in ADX+ALDO groups (groups IA and IIIA) versus groups I and III from the initial experiment in Figure $5 . \$ P \leq 0.005$ vs. group I; ${ }^{\star} P=0.005$ vs. group I. $n \geq 5$ per group. (B) Corresponding blood pressures. ${ }^{* *} P<0.0001$ vs. group IA; ${ }^{\#} P=0.006$ vs. group I. 


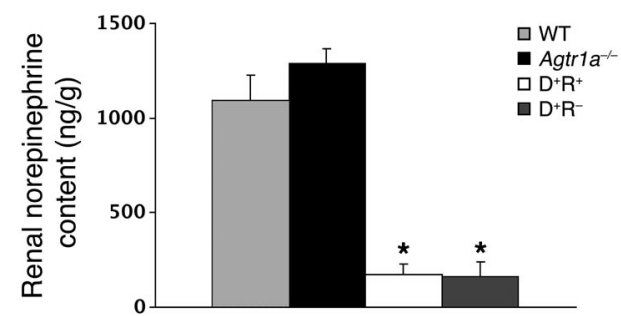

Figure 7

Renal norepinephrine content. Norepinephrine levels were measured in kidneys harvested from unmanipulated $\mathrm{Agtr1}^{+/+}$and $\mathrm{Agtr}^{-\mathrm{a}^{-/}}$mice as well as in kidney grafts harvested from $D^{+} R^{+}$and $D^{+} R^{-}$mice. ${ }^{\star} P<0.001$ vs. WT ( $n=5$ per group)

The importance of the RAS in clinical medicine is highlighted by the impressive cardiovascular efficacy of pharmacological agents that inhibit the synthesis or activity of angiotensin II. ACE inhibitors and ARBs are very effective and well tolerated antihypertensive agents (1). Along with their ability to lower blood pressure, these agents also ameliorate morbidity and mortality associated with cardiovascular diseases including congestive heart failure, coronary artery disease, and stroke $(33,34)$. The remarkably similar profiles of ACE inhibitors and ARBs in these disorders suggest a common mechanism underlying their efficacy: reducing $\mathrm{AT}_{1}$ receptor signaling in critical target tissues. Along with their expression in the kidney, $\mathrm{AT}_{1}$ receptors are present not only in the kidney but in myriad sites that may influence blood pressure including the vasculature, adrenal glands, and brain. Yet the key sites that determine the level of blood pressure cannot be precisely localized using pharmacological antagonists that block $\mathrm{AT}_{1}$ receptors in all tissues or in conventional gene targeting experiments. Accordingly, in the studies described here, we have used a renal cross-transplantation strategy to define the relative contributions of $\mathrm{AT}_{1 \mathrm{~A}}$ receptor actions in the kidney and in extrarenal tissues.

We found that absence of $\mathrm{AT}_{1 \mathrm{~A}}$ receptors in the kidney in $\mathrm{D}^{-} \mathrm{R}^{+}$ mice is sufficient to reduce blood pressure by almost $20 \mathrm{mmHg}$ (Figure 3), despite normal expression of receptors in all other tissues. These findings indicate that renal $\mathrm{AT}_{1 \mathrm{~A}}$ receptors have unique and nonredundant actions in blood pressure homeostasis. As aldosterone levels are unaffected in these $\mathrm{D}^{-} \mathrm{R}^{+}$animals, these observations show that blood pressure is regulated by direct effects of $\mathrm{AT}_{1}$ receptors on kidney cells, independent of any impact of mineralocorticoids. We suggest that this reduction in blood pressure is a direct consequence of interruption of $\mathrm{AT}_{1}$ receptor actions in the renal vasculature and/or renal epithelia that would otherwise reduce urinary sodium excretion. Our finding of sodium-sensitive blood pressure changes in animals lacking renal $\mathrm{AT}_{1 \mathrm{~A}}$ receptors is consistent with this conclusion. While the baseline blood pressures were significantly lower in the $\mathrm{D}^{-} \mathrm{R}^{-}$compared with the $\mathrm{D}^{-} \mathrm{R}^{+}$ group, the absolute magnitude of the blood pressure increases with high-salt feeding were similar, 17 and $15 \mathrm{mmHg}$, respectively, representing the component of blood pressure reduction due to sodium and volume deficits. Furthermore, it is likely that inhibition of these intrarenal pathways is an important mechanism for blood pressure lowering by ACE inhibitors and ARBs.

Although our studies support a vital role for the kidney in regulation of blood pressure, we find that $\mathrm{AT}_{1}$ receptors outside the kidney also make a unique contribution to blood pressure homeostasis that is virtually equivalent to and independent of the intrarenal actions of angiotensin II. Thus, we found that $\mathrm{D}^{+} \mathrm{R}^{-}$mice, which lack $\mathrm{AT}_{1 \mathrm{~A}}$ receptors in extrarenal tissues but have the normal complement of receptors in the kidney, also had blood pressure reductions of approximately $20 \mathrm{mmHg}$ (Figure 3). We considered the possibility that alterations of aldosterone release due to the absence of $\mathrm{AT}_{1}$ receptors in the zona glomerulosa of the adrenal gland might be responsible for low blood pressures in $\mathrm{D}^{+} \mathrm{R}^{-}$mice; this would be consistent with the hypothesis that control of renal sodium handling is the final common pathway for chronic blood pressure homeostasis. To test this possibility, we measured aldosterone excretion in $\mathrm{D}^{+} \mathrm{R}^{-}$mice and found that absence of $\mathrm{AT}_{1 \mathrm{~A}}$ receptors only in extrarenal tissues was associated with a reduction in aldosterone excretion of approximately 50\% compared with controls (Figure 5). Preservation of a partial aldosterone response in these mice is probably due to the presence of $\mathrm{AT}_{1 \mathrm{~B}}$ receptors, the minor murine $\mathrm{AT}_{1}$ receptor isoform. The adrenal cortex is one of the few tissues with appreciable expression of $\mathrm{AT}_{1 \mathrm{~B}}$ receptors (10).

In order to determine whether the reduced aldosterone generation in the $\mathrm{D}^{+} \mathrm{R}^{-}$mice was the cause of their low blood pressures, we clamped aldosterone at supraphysiological levels by chronic infusion into adrenalectomized $\mathrm{D}^{+} \mathrm{R}^{-}$and $\mathrm{D}^{+} \mathrm{R}^{+}$animals using osmotic pumps. The aldosterone levels in the 2 groups were similar, yet the blood pressures remained lower in the $\mathrm{D}^{+} \mathrm{R}^{-}$group lacking extrarenal $\mathrm{AT}_{1 \mathrm{~A}}$ receptors, compared with those in $\mathrm{D}^{+} \mathrm{R}^{+}$controls (Figure 6B). These findings corroborate other studies in which infusion of aldosterone alone failed to raise blood pressure (35) and suggest that the adrenal gland is not a critical site for blood pressure control by extrarenal $\mathrm{AT}_{1 \mathrm{~A}}$ receptors. We speculate instead that $\mathrm{AT}_{1 \mathrm{~A}}$ receptors in the $\mathrm{CNS}$ and/or in the vasculature are more likely to mediate the component of blood pressure regulation that is independent of the kidney. As our data on renal norepinephrine content indicate a persistent lack of sympathetic innervation in the transplanted kidneys (Figure 7), the contribution of extrarenal $\mathrm{AT}_{1}$ receptors to enhancing or modulating renal nerve activity and thereby altering renal excretory functions may be underestimated in these experiments. Therefore, the major actions of extrarenal $\mathrm{AT}_{1}$ receptors to regulate blood pressure in this model are likely to be due to effects on the vasculature. These could be direct actions of $\mathrm{AT}_{1 \mathrm{~A}}$ receptors on vascular smooth muscle cells (2) or indirect effects of $\mathrm{AT}_{1 \mathrm{~A}}$ receptors in the $\mathrm{CNS}$ to modulate vascular resistance (14). In this regard, recent studies have suggested that G-proteincoupled receptor actions in vascular smooth muscle make important contributions to chronic blood pressure homeostasis (36).

The availability of renin affects the generation of angiotensin II by the RAS, and renin expression is tightly controlled at the JGA

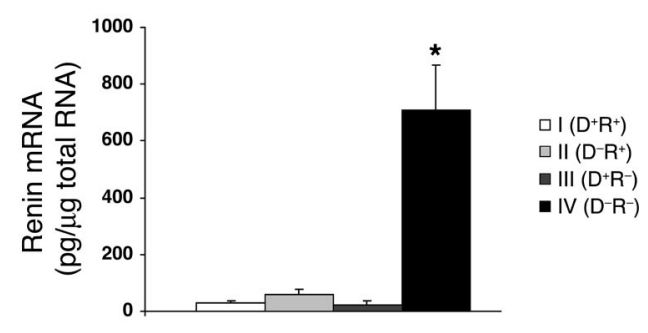

\section{Figure 8}

Kidney renin levels in the cross-transplantation groups. Kidneys were harvested at time of sacrifice. RNA was extracted using RNeasy protocol. Renin mRNA was quantitated by real-time PCR as described in Methods. ${ }^{*} P<0.003$ vs. other groups ( $n=5$ per group). 
in the kidney (37). Angiotensin II is an important component in the regulatory pathways for renin and may control its own synthesis by activating $\mathrm{AT}_{1}$ receptors at the JGA, thereby suppressing renin release $(18,25)$. The actions of ACE inhibitors and ARBs to increase renin mRNA expression and to cause JGA hypertrophy (38) have been cited as evidence supporting the existence of this so-called short-loop feedback mechanism. Although we find that renal $\mathrm{AT}_{1 \mathrm{~A}}$ receptors are key determinants of blood pressure, our studies do not indicate a major role for these receptors in regulating renin expression in the kidney.

In $\mathrm{D}^{-} \mathrm{R}^{+}$animals, which lack $\mathrm{AT}_{1 \mathrm{~A}}$ receptors only in the kidney, we found that renin mRNA levels are not significantly elevated despite the absence of $\mathrm{AT}_{1}$ receptors at the JGA and the significant reduction in blood pressure (Figure 8). Yet in the $\mathrm{D}^{-} \mathrm{R}^{-}$group completely lacking $\mathrm{AT}_{1 \mathrm{~A}}$ receptors, renin mRNA expression is increased more than 10 -fold above baseline. Because blood pressures are reduced even further in $\mathrm{D}^{-} \mathrm{R}^{-}$compared with $\mathrm{D}^{-} \mathrm{R}^{+}$animals, we posit that renal baroreceptor mechanisms are primarily responsible for the marked stimulation of renin associated with interruption of $\mathrm{AT}_{1}$ receptor signaling (28). Moreover, since blood pressure reductions of almost $20 \mathrm{mmHg}$ in $\mathrm{D}^{-} \mathrm{R}^{+}$or $\mathrm{D}^{+} \mathrm{R}^{-}$groups were not sufficient to trigger an increase in renin expression, our data also suggest that a threshold of blood pressure lowering must be achieved before the baroreceptor mechanisms are activated to stimulate renin production (27). The conclusion that blood pressure as such affects renin production is further supported by our observation that increasing blood pressure by dietary sodium loading significantly suppresses renin expression in $\mathrm{D}^{-} \mathrm{R}^{-}$mice. Taken together, our findings are consistent with previous studies by Matsusaka and colleagues showing that JGA hypertrophy is correlated with reduced blood pressure rather than with the absence of $\mathrm{AT}_{1}$ receptors at the JGA in chimeric $\mathrm{AT}_{1 \mathrm{~A}}$-null mice (39).

In summary, $\mathrm{AT}_{1}$ receptors in the kidney have unique actions to determine the normal level of blood pressure. These are direct effects of $\mathrm{AT}_{1}$ receptors on kidney cells that are independent of aldosterone and likely target renal vasculature and/or epithelia to modulate sodium excretion. While the $\mathrm{AT}_{1 \mathrm{~A}}$ receptors in the kidney are key determinants of blood pressure, they do not have a major role in regulating renin expression. Instead, our data indicate that baroreceptor mechanisms are dominant in the stimulation of renin production that is associated with absence of $\mathrm{AT}_{1}$ receptor signaling. We have also demonstrated that $\mathrm{AT}_{1}$ receptors outside the kidney make unequivocal and unique contributions to blood pressure homeostasis. These actions of extrarenal $\mathrm{AT}_{1 \mathrm{~A}}$ receptors cannot be explained by altered aldosterone generation alone, and they affect the basal level of blood pressure despite the presence of intact $\mathrm{AT}_{1 \mathrm{~A}}$ receptor pathways in the kidney. These studies illustrate the complexity of blood pressure regulation by the RAS and suggest that maximal efficacy of ACE inhibitors and ARBs requires complete blockade of renal and extrarenal pathways. Because these pharmacological inhibitors only ameliorate but do not prevent progressive renal disease and other complications, a more precise understanding of their mechanisms of blood pressure lowering and end-organ protection should lead to new opportunities for optimizing treatments for hypertension and its complications.

\section{Methods}

Animals. Mice lacking $\mathrm{AT}_{1 \mathrm{~A}}$ receptors for angiotensin II were generated by homologous recombination in embryonic stem cells as previously described (2). Animals were bred and maintained in the animal facility of the Durham Veterans Affairs Medical Center according to NIH guidelines with the approval of the Institutional Animal Care and Use Committees of the Duke University and Durham VA Medical Centers. Agtrla genotypes, designated "+" for the wild-type allele and "-" for the targeted allele, were determined by PCR analysis of DNA isolated from tail biopsies using the following primers: Agtr $1 a^{+/+}$upstream (5'-GCATCATCTTTGTGGTGGG-3') with a sequence common to both alleles, Agtr1a ${ }^{+/+}$downstream ( $5^{\prime}$-ATCAGCACATCCAGGAATG- $\left.3^{\prime}\right)$, and a sequence in the neomycin resistance cassette present only in the null allele (5'-TGCCGAGAAAG-

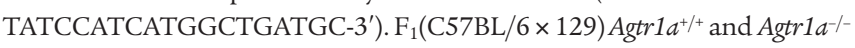
mice were generated from intercrosses of inbred $129 / \mathrm{SvEv}$ and $\mathrm{C} 57 \mathrm{BL} / 6$ Agtrla $a^{+-}$mice in which the Agtrla mutation had been back-crossed onto each respective background for more than 12 generations. We studied male $\mathrm{F}_{1}$ mice that were 2-4 months old.

Mouse kidney transplantation. Transplantation of a single mouse kidney with bilateral native nephrectomy was performed as we have described previously (40). Briefly, animals were anesthetized with isoflurane, and the donor kidney, ureter, and bladder were harvested en bloc, including the renal artery with a small aortic cuff and the renal vein with a small caval cuff. These vascular cuffs were anastomosed to the recipient abdominal aorta and vena cava, respectively, below the level of the native renal vessels. Total ischemic time averaged 35-40 minutes. Donor and recipient bladders were attached dome to dome. The right native kidney was removed at the time of transplant, and the left native kidney was removed through a flank incision 1-3 days later; care was taken to preserve the recipient adrenal glands intact with their normal blood supply. Overall surgical mortality was approximately $5 \%$. Each experimental group included at least 6 animals.

Data collection was initiated 2 weeks after transplantation to allow resolution of any ischemic injury associated with the transplant procedure. In addition, at the end of the experiments, sections of kidney grafts were examined to confirm normal renal structure, including the absence of ischemic tubular damage. In previous studies, we have found that glomerular filtration rates in syngeneic mouse renal transplants are similar to those observed in uninephrectomized mice (40).

Radiotelemetry transmitter implantation. We used a radiotelemetry system (Transoma Medical) to monitor blood pressure in conscious mice, as described previously (41). Six to 8 days after the kidney transplantation procedure, mice were anesthetized with isofluorane, and a pressure-sensing catheter was implanted into the left carotid artery, as described previously (42). The transducer unit was then inserted into a subcutaneous pouch along the right flank generated by blunt dissection inferiorly from the original neck incision. Mice were allowed to recover for 7 days after surgery to regain their normal circadian rhythms before experiments were initiated. During the time that their blood pressures were being monitored, mice were housed in a monitoring room in the animal facility where quiet is maintained and no other activities are permitted. In separate experiments using identical procedures, catheters were also implanted into otherwise unmanipulated Agtr $1 a^{+/+}$and Agtr1 $1 a^{-/-}$mice.

Blood pressure analysis. Arterial pressure recordings from unanesthetized, unrestrained animals were collected, stored, and analyzed using Dataquest A.R.T. software (version 2.2; Transoma Medical). The blood pressure data were collected continuously with sampling every 5 minutes for 10 -second intervals (41) during the prescribed time periods. In some experiments, pressures were recorded continuously for at least 48 hours. Otherwise, in order to conserve battery function, we carried out blood pressure measurements between 10:00 am and 2:00 pm during the appointed days of the protocol.

Experimental protocol. Baseline blood pressures were measured on 2 consecutive days while the animals ingested a conventional diet containing $0.4 \%$ sodium chloride. Mean blood pressure values for each animal were computed as the average of these measurements. After baseline blood pres- 
sure levels were established, mice from each of the experimental groups were placed on high-salt $(6 \% \mathrm{NaCl})$ diet (Harlan Teklad) for 1 week while continuously monitoring blood pressures. After the blood pressure measurements were taken, the mice were placed in metabolic cages, and urine was collected for 24 hours. Urinary aldosterone concentrations were determined by ELISA (Aldosterone Enzyme Immunoassay Kit) according to the manufacturer's instructions (Cayman Chemical). At the end of the experiment, the animals were anesthetized, blood was collected via intracardiac puncture, and the transplanted kidney was harvested.

Aldosterone infusions. In separate experiments, we performed bilateral adrenalectomy on selected groups of transplanted animals and infused them chronically with aldosterone in order to clamp aldosterone levels within a uniform range. Adrenalectomies were performed coincident with the native nephrectomies. At the time of the second nephrectomy and adrenalectomy, an osmotic minipump (ALZET model 2004; DURECT Corporation) containing aldosterone (A12930; Pfaltz \& Bauer) and dexamethasone (D-1756; Sigma-Aldrich) was placed in a subcutaneous pouch. The doses of aldosterone $(1 \mu \mathrm{g} /$ day $)$ and dexamethasone $(1.2 \mu \mathrm{g} / 100 \mathrm{~g}$ body wt/d) were chosen to provide near-physiological replacement based on published studies $(43,44)$. The aldosterone and dexamethasone were dissolved in polyethylene glycol 400 (Sigma-Aldrich) (45) and further diluted in normal saline. All other experimental procedures were carried out as described above.

Measurement of renal norepinephrine levels. Kidney specimens were placed in cold $0.1 \mathrm{~N} \mathrm{HCl}$ and were homogenized (24). To remove lipids from the homogenate, $0.1 \%$ Triton X-100 (Sigma-Aldrich) was added. The samples were then incubated at $37^{\circ} \mathrm{C}$ for 30 minutes and centrifuged (model 5417C; Eppendorf North America) at 9,600 g for 5 minutes. Renal norepinephrine was extracted from the supernatants and quantitated by enzyme immunoassay (NorAdrenaline EIA) according to the manufacturer's instructions (ALPCO Diagnostics).

Measurement of renin $m R N A$ levels. Relative levels of mRNA for renin were determined by real time RT-PCR with the ABI Prism 7700 Sequence Detection System (PE Biosystems Inc.) as described previously (46). Kidneys were harvested, and total RNA was isolated using an RNeasy Mini Kit per the manufacturer's instructions (QIAGEN). The nucleotide sequences of the
PCR primers and their fluorogenic probes have been published previously (46). Real time RT-PCR amplifications were performed in a 96-well plate in the ABI Prism 7700 sequence detector (PE Biosystems Inc.) as previously described (46). During the amplification, the fluorescence of FAM (or TET), TAMRA, and ROX (a passive reference dye) was measured by the 7700 sequence detector in each well of the 96-well plate. The numbers of copies of the PCR template in the starting sample were calculated using the Sequence Detector Software (SDS) included in the ABI Prism 7700 Sequence Detector System. A standard plasmid containing a DNA fragment for the renin gene was used as an external control, and amplification of the $\beta$-actin gene was used as an endogenous control. For each experimental sample, the amounts of the target and of the endogenous control were determined according to the appropriate standard curves.

Histopathology. To aid in the assessment of transplanted kidney viability, we fixed kidneys in formalin and sectioned and stained them with H\&E. The histomorphology of these organs was then examined by light microscopy.

Statistical analysis. The values for each parameter within a group are expressed as the mean \pm SEM. For comparisons between groups, statistical significance was assessed using ANOVA followed by unpaired Student's $t$ test adjusted for multiple comparisons. A paired Student's $t$ test was used for comparisons within groups (normal salt vs. high salt).

\section{Acknowledgments}

The authors acknowledge outstanding administrative support from Norma Turner. This work was supported by NIH grants HL49277 and HL56122 and by funding from the Medical Research Service of the Veterans Health Administration.

Received for publication September 16, 2004, and accepted in revised form January 4, 2005.

Address correspondence to: Thomas M. Coffman, Building 6/ Nephrology (111I), VA Medical Center, 508 Fulton Street, Durham, North Carolina 27705, USA. Phone: (919) 286-6947; Fax: (919) 286-6879; E-mail: tcoffman@acpub.duke.edu.
1. Husain, A., and Graham, R. 2000. Drugs, enzymes and receptors of the renin-angiotensin system: celebrating a century of discovery. Harwood Academic. Amsterdam, The Netherlands. 3-66.

2. Ito, M., et al. 1995. Regulation of blood pressure by the type $1 \mathrm{~A}$ angiotensin II receptor gene. Proc. Natl. Acad. Sci. U. S. A. 92:3521-3525.

3. Oliverio, M.I., Best, C.F., Smithies, O., and Coffman, T.M. 2000. Regulation of sodium balance and blood pressure by the $\mathrm{AT}(1 \mathrm{~A})$ receptor for angiotensin II. Hypertension. 35:550-554.

4. Guyton, A.C. 1991. Blood pressure control--special role of the kidneys and body fluids. Science. 252:1813-1816.

5. Shanmugam, S., and Sandberg, K. 1996. Ontogeny of angiotensin II receptors. Cell Biol. Int 20:169-176.

6. Timmermans, P.B., et al. 1993. Angiotensin II receptors and angiotensin II receptor antagonists. Pharmacol. Rev. 45:205-251.

7. Tharaux, P.L., and Coffman, T.M. 2001. Transgenic mice as a tool to study the renin-angiotensin system. Contrib. Nephrol. 135:72-91.

8. Murphy, T.J., Alexander, R.W., Griendling, K.K., Runge, M.S., and Bernstein, K.E. 1991. Isolation of a cDNA encoding the vascular type- 1 angiotensin II receptor. Nature. 351:233-236.

9. Sasaki, K., et al. 1991. Cloning and expression of a complementary DNA encoding a bovine adrenal angiotensin II type-1 receptor. Nature. 351:230-233.

10. Burson, J.M., Aguilera, G., Gross, K.W., and Sig- mund, C.D. 1994. Differential expression of angiotensin receptor $1 \mathrm{~A}$ and $1 \mathrm{~B}$ in mouse. Am. J. Physiol. 267:260-267.

11. Konishi, H., Kuroda, S., Inada, Y., and Fujisawa, Y 1994. Novel subtype of human angiotensin II type 1 receptor: cDNA cloning and expression. Biochem. Biophys. Res. Commun. 199:467-474.

12. Aguilera, G. 1992. Role of angiotensin II receptor subtypes on the regulation of aldosterone secretion in the adrenal glomerulosa zone in the rat. Mol. Cell. Endocrinol. 90:53-60.

13. Masilamani, S., Kim, G.H., Mitchell, C., Wade, J.B., and Knepper, M.A. 1999. Aldosterone-mediated regulation of $\mathrm{ENaC}$ alpha, beta, and gamma subunit proteins in rat kidney. J. Clin. Invest. 104:R19-R23.

14. Davisson, R.L., Oliverio, M.I., Coffman, T.M., and Sigmund, C.D. 2000. Divergent functions of angiotensin II receptor isoforms in the brain. J. Clin. Invest. 106:103-106.

15. Ichikawa, I., and Brenner, B.M. 1980. Importance of efferent arteriolar vascular tone in regulation of proximal tubule fluid reabsorption and glomerulotubular balance in the rat. J. Clin. Invest. 65:1192-1201.

16. Navar, L.G., Carmines, P.K., Huang, W.C., and Mitchell, K.D. 1987. The tubular effects of angiotensin II. Kidney Int. Suppl. 20:S81-S88.

17. Lorenz, J.N., et al. 1993. Effects of adenosine and angiotensin on macula densa-stimulated renin secretion. Am. J. Physiol. 265:F187-F194.
18. Shricker, K., Holmer, S., Kramer, B.K., Riegger, G.A., and Kurtz, A. 1997. The role of angiotensin II in the feedback control of renin gene expression. Pflugers Arch. 434:166-172.

19. Hall, J.E. 1986. Control of sodium excretion by angiotensin II: intrarenal mechanisms and blood pressure regulation. Am. J. Physiol. 250:R960-R972.

20. Okubo, S., et al. 1997. Angiotensin-independent mechanism for aldosterone synthesis during chronic extracellular fluid volume depletion. J. Clin. Invest. 99:855-860.

21. DiBona, G.F., and Sawin, L.L. 1983. Renal nerves in renal adaptation to dietary sodium restriction. Am. J. Physiol. 245:F322-F328.

22. Muratani, H., Teruya, H., Sesoko, S., Takishita, S., and Fukiyama, K. 1996. Brain angiotensin and circulatory control. Clin. Exp. Pharmacol. Physiol. 23:458-464.

23. DiBona, G.F. 1999. Central sympathoexcitatory actions of angiotensin II: role of type 1 angiotensin II receptors. J. Am. Soc. Nephrol. 10(Suppl.):S90-S94.

24. Mizelle, H.L., Hall, J.E., and Woods, L.L. 1988. Interactions between angiotensin II and renal nerves during chronic sodium deprivation. Am. J. Physiol. Renal Physiol. 255:F823-F827.

25. Oliverio, M.I., et al. 1998. Renal growth and development in mice lacking AT1A receptors for angiotensin II. Am. J. Physiol. 274:F43-F50.

26. Sugaya, T., et al. 1995. Angiotensin II type 1a receptor-deficient mice with hypotension and hyperreninemia. J. Biol. Chem. 270:18719-18722. 
27. Kirchheim, H., Ehmke, H., and Persson, P. 1988. Physiology of the renal baroreceptor mechanism of renin release and its role in congestive heart failure. Am. J. Cardiol. 62:68E-71E.

28. Bock, H.A., Hermle, M., Brunner, F.P., and Thiel, G. 1992. Pressure dependent modulation of renin release in isolated perfused glomeruli. Kidney Int. 41:275-280.

29. Cowley, A.W., Jr., and Roman, R.J. 1996. The role of the kidney in hypertension. JAMA. 275:1581-1589.

30. Aperia, A.C., Broberger, C.G., and Soderlund, S. 1971. Relationship between renal artery perfusion pressure and tubular sodium reabsorption. Am. J. Physiol. 220:1205-1212.

31. Guyton, A.C., et al. 1972. Arterial pressure regulation. Overriding dominance of the kidneys in longterm regulation and in hypertension. Am. J. Med. 52:584-594.

32. Hall, J.E., Brands, M.W., and Henegar, J.R. 1999. Angiotensin II and long-term arterial pressure regulation: the overriding dominance of the kidney. J. Am. Soc. Nephrol. 10(Suppl. 12):S258-S265.

33. Anonymous. 1992. Effect of enalapril on mortality and the development of heart failure in asymptomatic patients with reduced left ventricular ejection fractions. The SOLVD Investigators. N. Engl. J. Med. 327:685-691.
34. Yusuf, S., et al. 2000. Effects of an angiotensin-converting-enzyme inhibitor, ramipril, on cardiovascular events in high-risk patients. The Heart Outcomes Prevention Evaluation Study Investigators. N. Engl. J. Med. 342:145-153.

35. Lohmeier, T.E., Cowley, A.W., Jr., DeClue, J.W., and Guyton, A.C. 1978. Failure of chronic aldosterone infusion to increase arterial pressure in dogs with angiotensin-induced hypertension. Circ. Res. 43:381-390.

36. Tang, M.K., et al. 2003. Regulator of G-protein signaling- 2 mediates vascular smooth muscle relaxation and blood pressure. Nat. Med. 9:1506-1512.

37. Tobian, L., Tomboulian, A., and Janecek, J. 1959. The effect of high perfusion pressures on the granulation of juxtaglomerular cells in an isolated kidney. J. Clin. Invest. 38:605-610.

38. Gomez, R.A., et al. 1990. Recruitment of renin gene-expressing cells in adult rat kidneys. Am. J. Physiol. 259:F660-F665.

39. Matsusaka, T., et al. 1996. Chimeric mice carrying 'regional' targeted deletion of the angiotensin type $1 \mathrm{~A}$ receptor gene. Evidence against the role for local angiotensin in the in vivo feedback regulation of renin synthesis in juxtaglomerular cells. J. Clin. Invest. 98:1867-1877.

40. Coffman, T., et al. 1993. Improved renal function in mouse kidney allografts lacking MHC class I antigens. J. Immunol. 151:425-435.

41. Mills, P.A., et al. 2000. A new method for measurement of blood pressure, heart rate, and activity in the mouse by radiotelemetry. J. Appl. Physiol. 88:1537-1544.

42. Butz, G.M., and Davisson, R.L. 2001. Long-term telemetric measurement of cardiovascular parameters in awake mice: a physiological genomics tool. Physiol. Genomics. 5:89-97.

43. Rubera, I., et al. 2003. Collecting duct-specific gene inactivation of alphaENaC in the mouse kidney does not impair sodium and potassium balance. J. Clin. Invest. 112:554-565. doi:10.1172/ JCI200316956.

44. Kwon, T.H., et al. 2002. Regulation of collecting duct AQP3 expression: response to mineralocorticoid. Am. J. Physiol. Renal Physiol. 283:F1403-F1421.

45. Biller, K.J., Unwin, R.J., and Shirley, D.G. 2001. Distal tubular electrolyte transport during inhibition of renal 11beta-hydroxysteroid dehydrogenase. Am. J. Physiol. Renal Physiol. 280:F172-F179.

46. Kim, H.S., Lee, G., John, S.W., Maeda, N., and Smithies, O. 2002. Molecular phenotyping for analyzing subtle genetic effects in mice: application to an angiotensinogen gene titration. Proc. Natl. Acad. Sci. U. S. A. 99:4602-4607. 